\title{
Business Strategy, Technology Development and Characteristics of Asian Firms: An Empirical Study of the Hong Kong Electronics Industry
}

\author{
David $\mathrm{Ko}^{1} \&$ Cindy $\mathrm{Ge}^{1}$ \\ ${ }^{1}$ Department of Management \& Marketing, Faculty of Business, The Hong Kong Polytechnic University, Hung \\ Hom, Kowloon, Hong Kong, China \\ Correspondence: David Ko, Department of Management \& Marketing, Faculty of Business, The Hong Kong \\ Polytechnic University, Hung Hom, Kowloon, Hong Kong, China.
}

Received: February 1, 2018

Accepted: February 26, $2018 \quad$ Online Published: March 2, 2018

doi:10.20849/abr.v3i1.325

URL: https://doi.org/10.20849/abr.v3i1.325

\begin{abstract}
This research explores the phenomenon of firm performance as it relates to the business strategy, characteristics of Chinese Family Business (CFB) in Hong Kong's Electronic Companies, and technology strategy adopted by these firms. The motive to do this research is that there has been very little work on business strategy in export-oriented "developing economies - latecomer economies" as referred by Zahra and Covin (1993). There has also been little work on technology policy/strategy in Hong Kong, although there have been many suggestions that Hong Kong firms "need" to change and up-grade their business strategies. Added to this, Hong Kong firms have interesting characteristics (Chinese Family Business, CFB), which may be related to their business and technology strategies. Performance may be determined by the strategies they adopt. In this research, the key dimensions of "technology strategy/policy" are identified, including Imitation, Original Equipment Manufacturing (OEM) and Original Design Manufacturing (ODM), which are important in Hong Kong, but which have not been explored much in the literature. Hong Kong firms were selected in this topic since as China is found to become the world's manufacturing base and a lot of that industry, especially in Electronics Industry that this is an important topic.
\end{abstract}

Keywords: business strategy, technology policies and management characteristics of Chinese family firms

\section{Introduction}

\subsection{Background}

Hong Kong, being a small traditional fishing and agricultural village in the past, developed into a manufacturing port and became a noted international financial centre within decades. Due to her historical background of colonizing and the contribution of "positive non-interventionism" (laissez-faire policy) promoted by the Colony's former financial secretary Sir Phillips Haddon-Cave in 1978, a special environment emerged, acting as a large piece of fertile soil which favored the growth of various sectors. Of these, manufacturing sector might be seen as one of the most valuable stepping-stone in converting the conventional hamlet into a cosmopolitan city.

This legend was created by the local Chinese dynamic entrepreneurs who started their businesses in the 1960s which had been proved to be successes. They played a major role in catching up with the economically more advanced nations by narrowing the income gap between Western developed nations (leaders) and Hong Kong (latecomer) (Yu, 1998). Till now, over 85\% of industries are involving in the tertiary sector yet the increasingly blurred boundary between the secondary and tertiary sector (Yu, 1998; Davies \& Ko, 2006), manufacturing industry remains profitable.

\subsection{Definition of Electronics Industry}

Electronics sector is defined as that sector which manufactures electronic components and/or products containing electronic components (Reif, R., \& Sodini, C., 1997). According to Reif \& Sodini's classification in "The Hong Kong Electronics Industry", electronic products may be grouped into four categories, arranging the innovative content from the highest to lowest:

i. "Silver-Bullet" Products: Products that create a new market which require product innovation, e.g. iPod; 
ii. Novel Products: Products that begin a new product life cycle, e.g. nickel metal hydride battery;

iii. Enhanced Products: Value added products that customized for a particular market, e.g. telephones with call forwarding; and

iv. Original Equipment Manufacture (OEM) Products: Products that are requested and designed by a customer company.

\subsection{Electronics Industry in Hong Kong}

Being ranked as the freest economy in the world, the world's $11^{\text {th }}$ largest trading entity in terms of value of merchandise trade, the second largest recipient of foreign direct investment in Asia and one of the most competitive economies in Asia, Hong Kong proved to be a leading international trading and services hub as well as a high value-added manufacturing base and the gateway to the Mainland market. (Hong Kong Year Book 2005)

Electronics sector contributed to Hong Kong's Gross Domestic Production (GDP) to a great extent. According to the statistics from the Hong Kong Year Book 2005, electronics industry was the second largest domestic export-oriented major sector in Hong Kong (Chart 1), implying the high status performed by the industry.

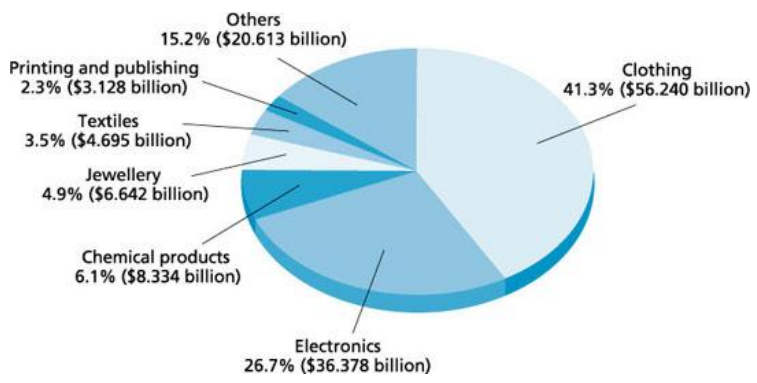

Figure 1. Value of domestic exports of the manufacturing sector in 2015

\subsection{Purposes of Research}

Thanks to technological prevalence and the keep-on increasing demand on electronic appliances, electronics industries recorded a massive growth. Hong Kong's electronics industries have long been treated as one of the city's most important and internationally competitive industries (Davies \& Ko, 2006; Reif \& Sodini, 1997). In addition, most of these electronics companies in Hong Kong are being categorized as Chinese Family Business (CFB). Therefore, identifying the characteristics of the CFB help further understand the success of this economic activity under the Hong Kong environment.

This study is going to discuss how the idiosyncratic CFB performs strategically and to measure the correlation between the CFB characteristics and the financial performance, hopefully analyzing the result and giving industrial contribution by setting up a "formula of success".

\subsection{Statements of Problems}

This research attempts to answer the following question:

i. What are the characteristics of Chinese Family Business in Hong Kong's electronics industry context?

ii. How these characteristics affect the adoption of business strategies?

iii. How these characteristics affect the adoption of technology strategies?

iv. Is there any association between Hong Kong manufacturing firms' performances and:

a) Product line breadth (H1a)

b) Environmental scanning (H1b)

c) Branding (H1c)

d) Production of specialty products (H1d)

e) China as a market for development (H1e)

f) ODM (H1f) 
g) Aggressive technological posture (H1g)

h) Process innovation (H1h)

i) New product development (H1i)

j) Cost leadership/emphasis on efficiency (H2a)

k) Price leadership (H2b)

1) China as a source of resources $(\mathrm{H} 2 \mathrm{c})$

m) OEM (H2d)

n) Imitation (H2e)?

\subsection{Research Objectives}

This study examines the relationship between the nature of the Chinese Family Business (CFB) stated above and the business strategies adopted in the setting of the Hong Kong electronics industry. Family firms and state-owned enterprises are the dominant indigenous forms of business in Asia (Claessens, Djankov, \& Lang, 1999), while the heaviest concentration of Chinese Family Firms (CFF) is in the manufacturing sector, or industrials (Shapiro, Gedajlovic, \& Erdener, 2003). It is observed that Chinese Family Firms share many of the salient features of other Asian family firms, and of family-owned business in general, while manifesting distinctive characteristics that reflect the unique historical and cultural experience of the Chinese people (Carney $\&$ Gedajlovic, 2002). Through this paper, the questions raised above are going to be investigated in depth.

\section{Literature Review}

\subsection{Characteristics of Chinese Family Business (CFB)}

There are extensive literatures on the studies of characteristics of Chinese Family Business. Based on prior theses published by Weber (1951), Ryan (1961), King and Leung (1975), and Wong (1985), Redding and Pugh (1986) surveyed 53 Hong Kong firms and suggested CFB were less formalized and role-specialized than Western firms while associating the phenomenon with Chinese familism and paternalism. Since then, researches were done by scholars to extend previous studies and drilled into the subject profoundly. Of them, Redding (1991, 1992, 1995) (Appendix i) and Whitley (1990, 1991, 1992) (Appendix ii) kept producing key papers within the field. In 1999, Harjani carried out a content analysis of various works in order to identify a set of 15 variables that could fully characterize CFB (Table 1).

Table 1. A summary of CFB characteristics (Harjani, 1999)

\begin{tabular}{|c|c|c|}
\hline \multicolumn{3}{|c|}{ Harjani's Summary of CFB Characteristics } \\
\hline $\begin{array}{l}\text { CEO dominance in } \\
\text { decision-making: one top person } \\
\text { in the firm is relied on to take } \\
\text { most decisions }\end{array}$ & $\begin{array}{l}\text { Family-centredness: the business } \\
\text { is regarded as family property } \\
\text { under strong family control }\end{array}$ & $\begin{array}{l}\text { Family financing: a preference for } \\
\text { and reliance on, familial sources of } \\
\text { finance }\end{array}$ \\
\hline $\begin{array}{l}\text { Antipathy to external } \\
\text { management: a strong reliance } \\
\text { on family members to fill senior } \\
\text { positions and antipathy to outside } \\
\text { professionals }\end{array}$ & $\begin{array}{l}\text { Paternalism: didactic and } \\
\text { patrimonial leadership style } \\
\text { requiring employee acceptance of } \\
\text { the owner's decisions }\end{array}$ & $\begin{array}{l}\text { Opportunistic diversification: } \\
\text { tendency to establish new business } \\
\text { ventures wherever profit } \\
\text { opportunities are preceived }\end{array}$ \\
\hline $\begin{array}{l}\text { Networking: extensive linkages } \\
\text { with other firms through a } \\
\text { complex web of deals, } \\
\text { obligations and ties }\end{array}$ & $\begin{array}{l}\text { Personalism of network } \\
\text { behaviour: business networking } \\
\text { is based on personal and social } \\
\text { networks }\end{array}$ & $\begin{array}{l}\text { Impermanence of connections: the } \\
\text { linkages between firms are no } \\
\text { permanent bonds, being changeable } \\
\text { and relatively short-term }\end{array}$ \\
\hline $\begin{array}{l}\text { Short-termism: a relatively short } \\
\text { time horizon and limited } \\
\text { long-term planning }\end{array}$ & $\begin{array}{l}\text { High degree of centralization: } \\
\text { limited delegation of authority by } \\
\text { the chief executive }\end{array}$ & $\begin{array}{l}\text { Low degree of formalization: the } \\
\text { firm is relatively unstructured and } \\
\text { there is limited use of written and } \\
\text { standardized control and coordination } \\
\text { procedures }\end{array}$ \\
\hline $\begin{array}{l}\text { Low degree of specialization: } \\
\text { managerial roles are diffuse and } \\
\text { shifting staff deal with a range of } \\
\text { tasks as required }\end{array}$ & $\begin{array}{l}\text { High emphasis on cost control: } \\
\text { the firm is very cost conscious } \\
\text { and sensitive to matters of } \\
\text { financial efficiency }\end{array}$ & $\begin{array}{l}\text { High emphasis on price leadership } \\
\text { the firm competes on price and is } \\
\text { willing to accept lower profit margins } \\
\text { if necessary }\end{array}$ \\
\hline
\end{tabular}


Till 2003, Davies and Ma reviewed the published papers, regenerated the conceptual work of the predecessors and adopted in the Hong Kong watch-making industry. While most literature measured the CFB characteristics of an organization by "high" or "low" degree and decided an organization is belong to the category of CFB accordingly, Davies and Ma suggested that the nature CFB should be described in terms of a set of continuous variables instead of assessing an organization as a matter of black and white: determining whether the firm is or is not a CFB.

In constructing the framework, certain variables are selected to characterize the "CFB-ness". The variable should meet the following four criteria: Firstly, it should reflect the debate about the most appropriate strategic direction for Hong Kong firms. Secondly, it should be relatively compact in order to protect the response rate and the validity of the responses. Thirdly, it should represent fundamental strategic choices that have been shown to impact on performance in a variety of settings. Fourthly, it should be made up of variables that have been shown to have validity and reliability beyond the American and European environment, preferably in an Asian setting and most particularly in the Chinese environment. Therefore, it is decided that the correlation among the level of cost control, system performance, business strategies (Table 2) including cost leadership, price leadership, product line breadth, environmental scanning, branding, specialty products, China for resources and China as market (Davies and Ma, 2003) and technological strategies (Table 3) including aggressive technological posture process innovation, new product development (Zahra, \& Covin, 1993), ODM, OEM and imitation (Yu, 1997; Berger \& Lester, 1997) will be examined.

Table 2. Business strategies measurement properties according to Davies and Ma, 2003

1. Emphasis on Efficiency / Cost Leadership. This captures the cost leadership (Porter 1985) or emphasis on efficiency aspect of strategy which has been closely associated with the traditional Hong Kong business model.

2. Price Leadership. Low prices are one of the key aspects of the traditional model. Davies and Ma (2003) found that price leadership was strongly associated with the traditional Chinese Family Business characteristics.

3. Product Line Breadth. The traditional approach of Hong Kong's small firms having been producing a narrowly focused line of commodity products, while larger capital involved is expected when product lines are expanded to meet a wider range of market needs.

4. Environmental Scanning. This indicates the extent that a firm exhibits an external orientation, being concerned to monitor and assess developments in its business environment. Davies and $\mathrm{Ma}$ (2003) found that this was significantly negatively associated with the defining characteristics of the traditional Chinese Family Business.

5. Branding. The traditional Hong Kong approach to business strategy avoided significant involvement in branding and product differentiation, which require patient capital (Carney \& Gedajlovic, 2001, 2003).

6. Specialty/Commodity Products. Commodity products are generally low-margin products suitable for the low price strategies which have been targeted by Hong Kong manufacturers traditionally. Specialty products require an element of differentiation which involves extra investment.

7. China as a Source of Resources. A new construct which firms emphasis on Mainland China as a means of accessing cheap intensive labour, raw materials, land and facilities, which are the key successful elements to adopt the cost leadership strategy (Porter, 1985). CFB gain the advantages of lowering unwanted overhead cost through treating China as a source of resources.

8. China as a Market. A new construct representing the extent to which firms seek to develop new markets on the Mainland, put forward by the Hong Kong Trade Development Council (HKTDC, 1998) as an important aspect of the move towards ODM and branding. 
Table 3 Technology strategies measurement properties according to Zahra and Covin, 1993

1. Aggressive technological posture. Referring to the extent of a firm seeking to position itself as a leader (Adler, 1989; Oster, 1990).

2. Process innovation. A unique construct in Hong Kong manufacturing industry focusing on "short-termism". (Hayes \& Wheelwright, 1984; Thurow, 1987) CFB emphasis on the methods to facilitate the process aiming at achieving efficiency.

3. New product development. This indicates the willingness of a firm to differentiate itself through developing new products (Brown, \& Eisenhardt, 1995). Studies of Zahra \& Covin (1993) and Davies (2002) showed significant associations between the dimensions of technology policy and the business strategies adopted by firms in Mainland China. As high investment is involved, which affect the cost directly, traditional CFB tends not to develop new products.

4. ODM. As proposed by the Hong Kong Trade Development Council $(1998,2000)$, firms should put more efforts on ODM in order to sustain. Participating in Original Design and Manufacturing will certainly increase cost involved. Cost control is negatively associated with OEM.

5. OEM. This arrangement relies on client's product designs and avoids costs and risks of identifying customer needs and specifying the products. To reduce unnecessary cost is Hong Kong's electronics central unique business model. Cost control is positively associated with OEM.

6. Imitation. In order to cut cost, firms try to reduce extra investment in invention and "copy" the design of other's. Although this may violate the intellectual property right, it is very common in the Mainland China.

\subsection{Proposed Framework and Hypotheses}

Referring to the foregoing literature review, a model is proposed in Figure 1 to correlate and extend the conceptual frameworks of Davies \& Ma (2003) and Davies \& Harjani (1999) as well as to explain the relationships among organizational characteristics, business strategy, technology strategy and organization performance.
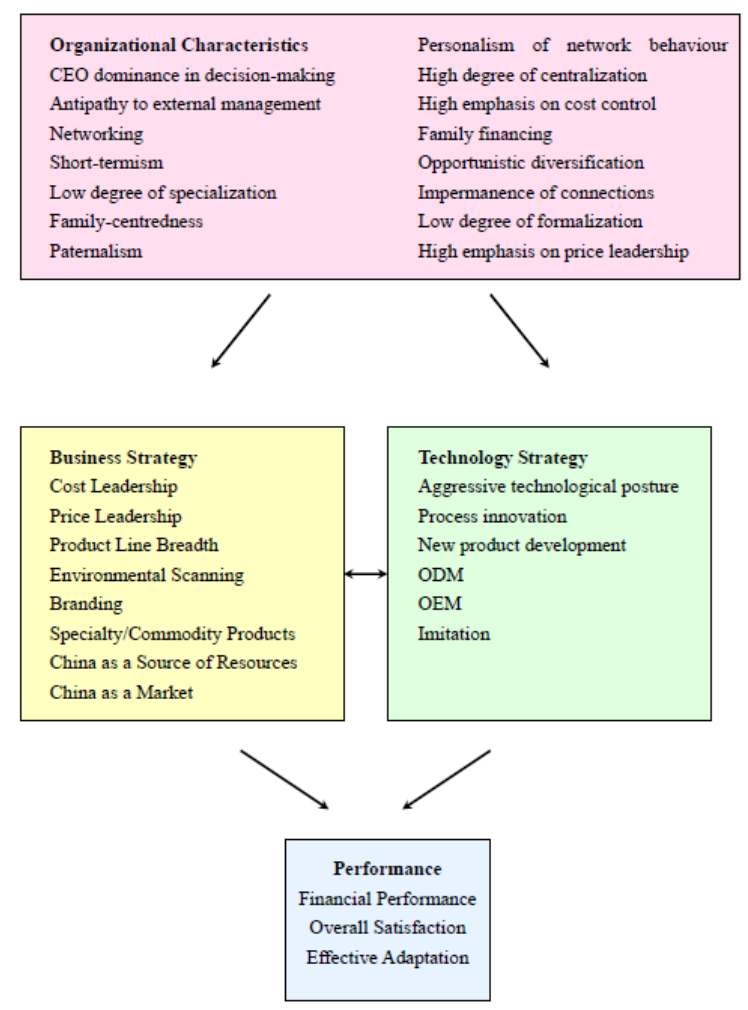

Figure 2. The relationships among organizational characteristics, business strategy, technology strategy and organization performance 
This research hypothesizes that:

H1: Performance amongst Hong Kong's manufacturing firms is positively associated with an emphasis on:

a) Product line breadth (H1a)

b) Environmental scanning (H1b)

c) Branding (H1c)

d) Production of specialty products (H1d)

e) China as a market for development (H1e)

f) ODM (H1f)

g) Aggressive technological posture (H1g)

h) Process innovation (H1h)

i) New product development (H1i)

H2: Performance amongst Hong Kong's manufacturing firms is negatively associated with an emphasis on:

a) Cost leadership/emphasis on efficiency (H2a)

b) Price leadership (H2b)

c) China as a source of resources $(\mathrm{H} 2 \mathrm{c})$

d) OEM (H2d)

e) Imitation (H2e)

\section{Methodology}

\subsection{Research Design}

This study is conducted in a quantitative method by use of questionnaires. Quantitative research was done through distribution of questionnaire to the sampling units with Chinese version only. Prior to implementation and pre-testing, the questionnaire was translated into Chinese and then back translated for accuracy.

\subsection{Sampling Plan and Sample Size}

The target respondents were defined as the rank of senior managers or above of all Hong Kong-based firms producing electronic products or parts. The most appropriate available sampling frame for Hong Kong-based electronic firms is the Membership Directory of the Hong Kong Electronics Association. 3,000 member firms with Hong Kong addresses, stated to be manufacturing electronic parts and components, computers, electronic toys and electronic watches were being listed.

\subsection{Questionnaire Design}

All variables used in this study have been measured satisfactorily in previous work, and in Chinese. Hence the same measurement scales were adopted here.

In order to obtain a high response rate with limited resources, the Total Design Method (TDM) was used in designing the survey package (Dillman, 1978). Firstly, the questionnaires were sent with a cover letter explaining the nature and significance of the research. The cover letter also explained that not more than 15 minutes of respondents' time would be needed to complete the questionnaire and a pre-paid envelope was enclosed. The body of the questionnaire did not ask for the name of the company or the respondent in an attempt to avoid distortion through socially desirable responses (Adler, Campbell \& Laurent, 1989).

The structured questionnaire is divided into six sections, which employed with multiple-choice questions, open-ended questions and Likert scale questions.

Part 1 aimed at identifying the official status of the respondent. Only those who ranked manager or above would be considered as valid respond, as most information asked in the questionnaire was restricted beyond the management level.

Part 2 intended to recognize the general information of the respondent's company including the location, size, operating years, nature and operating practice of the firm.

Part 3 further distinguished the nature of the respondent's firm. A seven-point Likert scale system (1=Very Strongly Disagree, $7=$ Very Strongly Agree) is used to measure the CFB-ness of the target company.

Part 4 focused on the business strategies practices, suggested by Davies and Ma (2003), in the responding 
company. Seven-point Likert scale is adopted (1=Not Important At All, 7=Most Important).

Part 5 consisted the statements of Zahra and Covin (1993) about technology strategies. Seven-point Likert scale is used (1=Very Strongly Disagree, 7=Very Strongly Agree).

Part 6 measured the company performance in terms of financial performance, overall satisfaction and effective adaptation. Again, seven-point Likert scale is used (1=Very Strongly Disagree/Very Poor Performance, 7=Very Strongly Agree/Excellent Performance).

\section{Analysis and Findings}

\subsection{Demographics}

In this research, a total of 366 questionnaires were collected. A description of responding firms' profile is shown in Table 4.

Of the sample, most respondents $(47.5 \%)$ were directors or general mangers. $16.7 \%$ were the owners while $35.8 \%$ were in senior titles. The electronic parts \& components constitutes the largest proportion of the sample with $155(42.3 \%$ ) respondents, while electronics toys, computers \& peripherals, and electronic watches \& clocks shared the remaining for $57(15.6 \%), 45(12.6 \%)$ and $44(12.0 \%)$ respectively.

Table 4. Profile of responding firms $(n=366)$

\begin{tabular}{|c|c|c|c|}
\hline No. of Firms (\%) & & No. of Firms (\%) & \\
\hline Type of products & & Range of products & \\
\hline Electronic parts \& components & $155(42.3)$ & 1 category only & $268(73.2)$ \\
\hline Computers \& peripherals & $46(12.6)$ & 2 categories & $61(16.7)$ \\
\hline Electronic toys & $57(15.6)$ & 3 categories & $25(6.9)$ \\
\hline Electronic watches \& clocks & $44(12.0)$ & 4 categories & $8(2.2)$ \\
\hline Radios and recorders & $35(1.4)$ & 5 or more categories & $4(1.0)$ \\
\hline Telephones & $33(0.8)$ & & \\
\hline Other products & $134(15.3)$ & & \\
\hline Employment in Hong Kong & & Employment in China & \\
\hline Mean & 44 & Mean & 1240 \\
\hline Maximum & 1200 & Maximum & 72000 \\
\hline Minimum & 1 & Minimum & 1 \\
\hline Less than 10 employees & $161(44)$ & 1-50 employees & $86(23.5)$ \\
\hline 11-20 employees & $70(19.1)$ & 51-100 employees & $28(7.7)$ \\
\hline 21-50 employees & $81(22.1)$ & 101-200 employees & $49(13.4)$ \\
\hline 51-100 employees & $26(7.1)$ & 201-500 employees & $70(19.1)$ \\
\hline 100+ employees & $28(7.7)$ & 500+ employees & $133(36.3)$ \\
\hline \multicolumn{4}{|l|}{$\begin{array}{l}\text { Years experience in the } \\
\text { electronics industry }\end{array}$} \\
\hline Mean & 14.2 & & \\
\hline Maximum & 50 & & \\
\hline Minimum & 2 & & \\
\hline
\end{tabular}

\subsection{Relationships Amongst CFB Characteristics and Business Strategies}

To illustrate the relationships amongst CFB characteristics and business strategies, a table of correlations 
between the two is prepared. The following tables adapt a two-factor model.

As seen in the results, the characteristics of CFB are significantly positively associated with more traditional strategies and negatively correlated with strategies newly recommended by the TDC. Take paternalism as an example. The mentioned variable is positively related to price leadership and China for resources, which are part of traditional Hong Kong approach to competition, at significant levels. Similarly, personalism of networks, which limited the horizontal development of a company, is negatively associated with strategies that require external orientation while positively correlated with the traditional approach. Formalization was negatively related to cost leadership, product line breadth, environmental scanning, branding, specialty product, China for resources and China as market. For short-termism, results showed that it is negatively associated with cost leadership, environmental scanning, specialty product and China as market. Information networking and specialization were shown as positively related with cost leadership, product line breadth, environmental scanning, specialty products, China as market, price leadership and branding as well as China for resources; familism was shown as positively correlated with China for resources; antipathy to external management showed negative relationship with environmental scanning; while centralization showed positive relationship with price leadership but negatively related with cost leadership, environmental scanning and specialty products.

In short, paternalism, personalism of networks, familism, antipathy to external management, centralization, short-termism, price leadership and china for resources provided sound support to the hypothesis that CFB is positively associated with traditional approach and negatively related to newly proposed form of business. On the country, cost leadership, environmental scanning, specialty products, specialization, China as market, product line breadth, branding and formalization contradicted the hypothesis.

Table 5. Correlations for CFB characteristics and business strategies

\begin{tabular}{|c|c|c|c|c|c|c|c|c|c|c|c|c|c|c|c|c|c|}
\hline & 1 & 2 & 3 & 4 & 5 & 6 & 7 & 8 & 9 & 10 & 11 & 12 & 13 & 14 & 15 & 16 & 17 \\
\hline 1. Paternalism & & .10 & $.27^{* *}$ & $.36 * *$ & $.16^{* *}$ & .03 & $.59 * *$ & -.07 & $.11^{*}$ & .08 & $.22^{* *}$ & .04 & -.05 & -.06 & .04 & $.25 * *$ & -.04 \\
\hline 2. Information & & & .05 & -.03 & .06 & $.26 * *$ & -.01 & $.14 *$ & -.03 & $.23 * *$ & $.15^{*}$ & $.29 * *$ & $.30^{*}$ & $.18 *$ & $.22 * *$ & .12 & $.28 * *$ \\
\hline \multicolumn{18}{|l|}{ Networking } \\
\hline 3. Personalism of & & & & $.27 * *$ & $.26^{* * *}$ & $-.19 * *$ & $.30^{* *}$ & $-.18^{*}$ & $.39^{* * *}$ & -.03 & $.13 *$ & $-.17^{*}$ & $-.15^{*}$ & $-.17^{*}$ & $-.12^{*}$ & .05 & -.10 \\
\hline \multicolumn{18}{|l|}{ Networking } \\
\hline 4. Familism & & & & & 00 & -.03 & $.40^{* *}$ & $-.13 *$ & $.21^{* *}$ & -.02 & .01 & -.23 & .10 & -.03 & -.10 & $.16^{*}$ & -.04 \\
\hline 5. Antipathy to & & & & & & -.02 & $.18^{* *}$ & -.04 & $.21^{* *}$ & -.07 & -.02 & .01 & $-.23^{* *}$ & .10 & .03 & .03 & .01 \\
\hline \multicolumn{18}{|l|}{ External } \\
\hline \multicolumn{18}{|l|}{ Management } \\
\hline 6. Formalization & & & & & & & 00 & $.64^{* *}$ & $-.27^{* *}$ & $-.29 * *$ & .10 & $-.28 * *$ & $-.33 * *$ & $-.22 * *$ & $-.23 * *$ & $-.13 *$ & $-.19 *$ \\
\hline 7. Centralization & & & & & & & & $.45^{* *}$ & $.25^{* *}$ & $-.16 * *$ & $.19^{* *}$ & .06 & $-.18^{* *}$ & .09 & $-.12 * *$ & .07 & .03 \\
\hline 8. Specialization & & & & & & & & & $-.28 * *$ & $.35 *$ & .08 & $.23 * *$ & $.38 * *$ & .04 & $30 * *$ & $.19 * *$ & $.20^{* *}$ \\
\hline 9. Short-termism & & & & & & & & & & $-.18 *$ & .08 & -.02 & $-.32 * *$ & -.02 & $-.27 * *$ & -.03 & $-.18^{* *}$ \\
\hline 10. Cost leadership & & & & & & & & & & & .07 & .10 & $.38 * *$ & $.12^{*}$ & $.31^{* *}$ & $.29 * *$ & $.20^{* *}$ \\
\hline 11. Price leadership & & & & & & & & & & & & $.27 * *$ & $.37^{* *}$ & $.29 * *$ & $.19^{* *}$ & $.07 * *$ & $.34 * *$ \\
\hline 12. Product line & & & & & & & & & & & & & $.20^{* *}$ & .06 & .08 & .23 & $-.10^{*}$ \\
\hline \multicolumn{18}{|l|}{ breadth } \\
\hline 13. Environmental & & & & & & & & & & & & & & $.29 * *$ & $.32 * *$ & .01 & $.21^{* *}$ \\
\hline \multicolumn{18}{|l|}{ scanning } \\
\hline 14. Branding & & & & & & & & & & & & & & & $.24 * *$ & $.21 * *$ & $.54 * *$ \\
\hline 15. Specialty & & & & & & & & & & & & & & & & -.05 & $.15^{* *}$ \\
\hline \multicolumn{18}{|l|}{ products } \\
\hline 16. China for & & & & & & & & & & & & & & & & & $.11^{*}$ \\
\hline \multicolumn{18}{|l|}{ resources } \\
\hline 17. China as market & & & & & & & & & & & & & & & & & \\
\hline
\end{tabular}

**/* Significant at the $.01 / .05$ levels.

\subsection{Relationships Amongst CFB Characteristics and Technology Strategies}

For the part of technology strategies, same approach is adopted to analysis the result. By fitting into the two-factor model for each pair of constructs in Table 6, correlations between the characteristics of CFB and technology strategies can be examined.

As the table demonstrates, the defined CFB characteristics showed tension against the more aggressive approach towards technological development. Paternalism is displayed to be negatively related with aggressive technological posture. On top of this, statistics signified familism is in inverse ratio with aggressive 
technological posture, process innovation and new product development. Information networking, personalism of networking and formalization showed positive relationship with process innovation, OEM and imitation; specialization and short-termism are positively correlated to aggressive technological posture, new product development and ODM while negatively related with process innovation and imitation; centralization showed positive relationship with aggressive technological posture, new product development, OEM and ODM. For the technology strategy which has long been adopted by the industry e.g. OEM, it recorded positive relationships with a number of CFB characteristics such as paternalism, personalism of networking, formalization and short-termism.

To sum up, the CFBness of a corporation affect the usage of technology strategies. In brief, they tended to adopt more "traditional" strategies in operating their business, which is proved by the negative relationship between natures of CFB and the strategy variables.

Table 6. Correlations for CFB characteristics and technology strategies

\begin{tabular}{|c|c|c|c|c|c|c|c|c|c|c|c|c|c|c|c|}
\hline & 1 & 2 & 3 & 4 & 5 & 6 & 7 & 8 & 9 & 10 & 11 & 12 & 13 & 14 & 15 \\
\hline 1. Paternalism & & .10 & $.27 * *$ & $.36 * *$ & $.16^{* *}$ & .03 & $.59 * *$ & -.07 & $.11^{*}$ & -.01 & -.04 & $.12 *$ & $.12 *$ & -.01 & $.12 *$ \\
\hline 2. Information & & & .05 & -.03 & .06 & $.26^{* *}$ & -.01 & $.14 *$ & -.03 & .01 & .01 & $.23^{* *}$ & $.18^{* *}$ & .01 & $.23 * *$ \\
\hline \multicolumn{16}{|l|}{ Networking } \\
\hline 3. Personalism of & & & & $.27 * *$ & $.26^{* *}$ & $-.19 * *$ & $.30 * *$ & $-.18 *$ & $.39 * *$ & -.07 & -.08 & $.21^{* *}$ & $.13^{* *}$ & -.07 & $.21 * *$ \\
\hline \multicolumn{16}{|l|}{ Networking } \\
\hline 4. Familism & & & & & .00 & -.03 & $.40 * *$ & $-.13 *$ & $.21 * *$ & $-.13 * *$ & -.03 & .09 & $.16^{* *}$ & $-.13 * *$ & .09 \\
\hline 5. Antipathy to & & & & & & -.02 & $.18 * *$ & -.04 & $.21^{* *}$ & .03 & .02 & -.07 & .04 & .03 & -.07 \\
\hline \multicolumn{16}{|l|}{ External } \\
\hline \multicolumn{16}{|l|}{ Management } \\
\hline 6. Formalization & & & & & & & .00 & $.64^{* *}$ & $-.27 * *$ & -.11 & -.06 & $.16^{* *}$ & $.20 * *$ & -.10 & $.16 * *$ \\
\hline 7. Centralization & & & & & & & & $.45^{* *}$ & $.25^{* *}$ & $-.24 * *$ & $.41^{* *}$ & -.04 & $.11^{*}$ & $.25 * *$ & -.04 \\
\hline 8. Specialization & & & & & & & & & $-.28 * *$ & $.72 *$ & $.72 * *$ & $-.31 * *$ & -.01 & $.72 * *$ & $-.31 * *$ \\
\hline 9. Short-termism & & & & & & & & & & $-.66^{*}$ & $.66 * *$ & $-.18^{* *}$ & .02 & $.66 * *$ & $-.18 *$ \\
\hline 10. Branding & & & & & & & & & & & $.72 * *$ & $.65^{* *}$ & $-.31 * *$ & $.53 * *$ & -.01 \\
\hline 11. New Product & & & & & & & & & & & & $.66^{* *}$ & $-.26 * *$ & $.61^{* *}$ & .07 \\
\hline \multicolumn{16}{|l|}{ Development } \\
\hline 12. Process & & & & & & & & & & & & & $-.18 * *$ & $.41 * *$ & .02 \\
\hline \multicolumn{16}{|l|}{ innovation / New } \\
\hline \multicolumn{16}{|l|}{ process development } \\
\hline 13. OEM & & & & & & & & & & & & & & $-.37 * *$ & $.13 *$ \\
\hline 14. ODM & & & & & & & & & & & & & & & $.21^{* *}$ \\
\hline 15. Imitation & & & & & & & & & & & & & & & \\
\hline
\end{tabular}

**** Significant at the $.01 / .05$ levels.

\subsection{Relationship Between Adoption of Strategies and Organizational Performance}

According to Hair, Anderson, Tatham \& Black's paper published in 1998, a measurement model including 14 variables would contain too many parameters relative to the sample size of 366 . Hence the constructs were grouped into associated sets including

a. Business Strategy e.g. Emphasis on efficiency, Product line breadth, Price leadership, Branding, Environmental scanning, Commodity/specialty products, China as a market, China for resources;

b. Zahra and Covin's Technology Policy e.g. Aggressive technological posture, Process innovation, New product development;

c. New Technology Policy e.g. Original equipment manufacture, Original design and manufacture, Imitation/competition-based technology development; and

d. Performance e.g. Satisfaction with the achievement of strategic objectives, Effective adaptation, Financial performance; in order to evaluate their dimensionality and reliability.

Table 7 shows the means, standard deviations, co-efficient variances for CFB characteristics and the strategy variables in correction matrix. 
Table 7. Correlations for performance and strategy variables

\begin{tabular}{|c|c|c|c|c|c|c|c|c|c|c|c|c|c|c|c|c|c|}
\hline & Mean & S.D. & $\mathrm{CV}$ & 2 & 3 & 4 & 5 & 6 & 7 & 8 & 9 & 10 & 11 & 12 & 13 & 14 & 15 \\
\hline 1. System & 4.4 & 0.88 & & $.16^{* *}$ & .02 & $.16^{* *}$ & $.30^{* *}$ & $.14^{* *}$ & $.30^{* *}$ & .09 & $.12^{*}$ & $32^{* *}$ & $.35^{* *}$ & $36^{* *}$ & $-.11^{*}$ & $.34^{* *}$ & -.08 \\
\hline \multicolumn{18}{|l|}{ performance } \\
\hline 2. Cost leadership & 5.58 & 1.00 & .32 & & $.11^{*}$ & $.25^{* *}$ & $.42^{* *}$ & .09 & $.29^{* *}$ & $.35^{* *}$ & $.11^{*}$ & $.12^{*}$ & .08 & $.16^{* *}$ & .02 & .10 & .01 \\
\hline 3. Price leadership & 4.12 & 1.12 & .17 & & & $.25^{* *}$ & .06 & $.21^{* *}$ & $-.12^{*}$ & $.25^{* *}$ & .09 & -01 & -01 & -.02 & $.13^{*}$ & .01 & $.28^{* *}$ \\
\hline 4. Product line & 4.94 & 1.07 & .24 & & & & $.33^{* *}$ & $.41^{* *}$ & $.29^{* *}$ & .10 & $.22^{* *}$ & $.34^{* *}$ & $.37^{* *}$ & $.29^{* *}$ & -.04 & $.25^{* *}$ & $.16^{* *}$ \\
\hline \multicolumn{18}{|l|}{ breadth } \\
\hline 5. Environmental & 5.26 & 0.96 & 15 & & & & & $.29^{* *}$ & $.55^{* *}$ & $.21^{* *}$ & $.24^{* *}$ & $39^{* *}$ & $.35^{* *}$ & $.32^{* *}$ & $-.11^{*}$ & $.29^{* *}$ & .04 \\
\hline \multicolumn{18}{|l|}{ scanning } \\
\hline 6. Branding & 4.00 & 1.24 & 21 & & & & & & $.21^{* *}$ & .01 & $.32^{* *}$ & $.38^{* *}$ & $.31^{* *}$ & $.25^{* *}$ & $-18^{* *}$ & $.28^{* *}$ & $.19^{* *}$ \\
\hline 7. Specialty products & 5.14 & 1.04 & 34 & & & & & & & $.12^{*}$ & $.15^{* *}$ & $.44^{* *}$ & $.49^{* *}$ & $.35^{* *}$ & $-.11^{*}$ & $.41^{* *}$ & -.02 \\
\hline 8. China for resources & 5.70 & 1.23 & 29 & & & & & & & & -05 & -.07 & -.08 & -.04 & $.13^{*}$ & -.00 & $.16^{* *}$ \\
\hline 9. China as market & 4.33 & 1.72 & 19 & & & & & & & & & $.29^{* *}$ & $.18^{* *}$ & $.20^{* *}$ & $-12^{*}$ & $.16^{* *}$ & .10 \\
\hline 10. Aggressive & 4.60 & 1.31 & .26 & & & & & & & & & & $.72^{* *}$ & $.66^{* *}$ & $-.35^{* *}$ & $.51^{* *}$ & -.08 \\
\hline \multicolumn{18}{|l|}{ technological } \\
\hline \multicolumn{18}{|l|}{ posture } \\
\hline 11. New product & 4.67 & 1.20 & .19 & & & & & & & & & & & $.66^{* *}$ & $-.31^{* *}$ & $.58^{* *}$ & .01 \\
\hline \multicolumn{18}{|l|}{ development } \\
\hline 12. Process innovation/ & 4.60 & 1.20 & .34 & & & & & & & & & & & & $-.20^{* *}$ & $.37^{* *}$ & -.03 \\
\hline \multicolumn{18}{|l|}{ New process development } \\
\hline 13. OEM & 4.05 & 1.29 & 22 & & & & & & & & & & & & & $-.43^{* *}$ & $.16^{* *}$ \\
\hline 14. ODM & 4.59 & 1.37 & 16 & & & & & & & & & & & & & & $.13^{*}$ \\
\hline 15. Imitation & 4.03 & 1.10 & .30 & & & & & & & & & & & & & & \\
\hline
\end{tabular}

$* * / *$ Significant at the $.01 / .05 / .10$ levels.

These results demonstrate a number of points. First, the maximum correlation between any two constructs was .72, between the variables of aggressive technological posture and new product development, which means there is no evident threat to discriminant validity. Second, means for China for resources (5.70) and cost leadership (5.58) were the two highest among the variables, showing that respondents treasured these two strategies as the most important in the industry. Third, the coefficient of variation (CV) for price leadership was very low (.17) indicating that it was regarded as important in the respondents with slightly variance across sample.

In answering the questions raised and proving the hypotheses set above, regressions between company performance (in terms of financial performance, overall satisfaction and effective adaptation) and the strategies used are showed in Table 8 .

Table 8. Regressions of company performance and the strategies used

\begin{tabular}{llll}
\hline Strategies & $\begin{array}{l}\text { Financial } \\
\text { Performance }\end{array}$ & $\begin{array}{l}\text { Overall } \\
\text { Satisfaction }\end{array}$ & $\begin{array}{l}\text { Effective } \\
\text { Adaptation }\end{array}$ \\
\hline Business Strategies & & & \\
Product line breadth (H1a) & -.04 & -.02 & -.10 \\
Environmental scanning (H1b) & $.13^{*}$ & .09 & .08 \\
Branding (H1c) & .04 & -.02 & -.00 \\
Production of specialty products (H1d) & .03 & .02 & .05 \\
China as a market for development (H1e) & .04 & .01 & .01 \\
Cost leadership/emphasis on efficiency (H2a) & .03 & -.04 & .05 \\
Price leadership (H2b) & .02 & .02 & .07 \\
China as a source of resources (H2c) & .04 & .10 & .05 \\
Zahra and Covin's Technology Policy & & & \\
Aggressive technological posture (H1g) & -.03 & -.07 & -.05 \\
Process innovation (H1h) & .04 & $.22^{* * *}$ & $.30^{* * *}$ \\
New product development (H1i) & -.08 & $.13^{*}$ & $.14^{*}$ \\
New Technology Policy & & & \\
ODM (H1f) & $.19 * * *$ & $.24^{* * *}$ & $.21^{* * *}$ \\
OEM (H2d) & -.00 & .10 & $.12^{*}$ \\
Imitation (H2e) & $-.14^{* *}$ & $-.10^{*}$ & $-.15^{* * *}$ \\
$R^{2} /$ Adj. $R^{2}$ & $.10 / .06$ & $.21 / .18$ & $.30 / .27$ \\
$F /$ Sig. $F$ & $2.67 / .00$ & $6.68 / .00$ & $10.67 / .00$ \\
\hline
\end{tabular}

$* * * / * * / *$ Significant at the $.01 / .05 / .10$ levels. 
For business strategies, environmental scanning (H1b) is supported by showing the positive relationship (.13) with financial performance at a significant level.

For Zahra and Covin's technology policy, both process innovation (H1h) and new product development (H1i) are supported by showing positive relationship with overall satisfaction (.22 and .13 respectively) and effective adaptation (.30 and .14 respectively).

For the new technology policy, ODM (H1f) recorded positive regression figures in financial performance, overall satisfaction and effective adaptation. OEM (H2d) showed positive relation to effective adaptation (.12). While imitation $(\mathrm{H} 2 \mathrm{e})$ recorded negative regression figures within all the three fields of assessing company performance (-.14. -.10 and -.15 respectively).

Other variables in business strategies e.g. product line breadth (H1a), branding (H1c), production of specialty products (H1d), China as a market for development (H1e), cost leadership/emphasis on efficiency (H2a), price leadership (H2b) and China as a source of resources (H2c) and aggressive technological posture in Zahra and Covin's technology policy did not show any significant relations with company performance. Summary of the results of hypotheses testing is shown in Table 9.

Table 9. Summary of the results of hypotheses testing

\begin{tabular}{ll}
\hline Hypotheses & Results \\
\hline H1: Performance amongst Hong Kong's manufacturing firms is positively & \\
associated with an emphasis on: & \\
a) Product line breadth (H1a) & Not supported \\
b) Environmental scanning (H1b) & Partly supported \\
c) Branding (H1c) & Not supported \\
d) Production of specialty products (H1d) & Not supported \\
e) China as a market for development (H1e) & Not supported \\
f) ODM (H1f) & Supported \\
g) Aggressive technological posture (H1g) & Not supported \\
h) Process innovation (H1h) & Partly supported \\
i) New product development (H1i) & Partly supported \\
H2: Performance amongst Hong Kong's manufacturing firms is negatively & \\
associated with an emphasis on: & \\
a) Cost leadership/emphasis on efficiency (H2a) & Not supported \\
b) Price leadership (H2b) & Not supported \\
c) China as a source of resources (H2c) & Not supported \\
d) OEM (H2d) & Not supported \\
e) Imitation (H2e) & Supported \\
\hline
\end{tabular}

\section{Discussion}

The above findings are based on about 300 respondents who were being asked to reflect their companies' strategies used and companies' performances. A number of results emerge from the analyses.

\subsection{The Characteristics of $C F B$}

For the characteristics of the CFB-ness, specialization, paternalism and information networking are the three categories with highest mean score (Table 10), implying that these three natures are the most commonly found characteristics in the electronics industry in Hong Kong. 
Table 10. Descriptive statistics of CFB variables

\begin{tabular}{lllll}
\hline & Min & Max & Mean & Std. Deviation \\
\hline 1. Paternalism & 1.60 & 7.00 & 4.95 & .96 \\
2. Information Networking & 2.00 & 7.00 & 4.68 & .91 \\
3. Personalism of Networking & 1.00 & 7.00 & 3.81 & 1.07 \\
4. Familism & 1.00 & 7.00 & 3.15 & 1.66 \\
5. Antipathy to External Management & 1.00 & 7.00 & 4.07 & .90 \\
6. Formalization & 1.50 & 7.00 & 4.51 & .88 \\
7. Centralization & 1.00 & 7.00 & 3.94 & 1.19 \\
8. Degree of Specialization & 1.00 & 7.00 & 5.01 & .90 \\
9. Short-termism & 1.33 & 5.33 & 3.63 & .62 \\
\hline
\end{tabular}

Surprisingly, the degree of specialization received the highest mean score, which suggested that companies of electronics industry in Hong Kong are not as "traditional" and "classical" as found in previous study (Kienzle, Rene, \& Mark Shadur, 1997).

\subsection{Adoption of Business Strategies}

While these three are the most prevalent CFB characteristics in the sector, they play important roles in influencing the adoption of different kind of strategies. In general, the characteristics of CFB suggested a more traditional way of using business strategies in corporation.

Undoubtedly, paternalism is positively related with price leadership and China for resources as predicted. However, a trend of change is noted in the result analysis. Information networking is positively correlated not only to cost leadership, price leadership and product line breadth which are the more conservative strategies, but also environmental scanning, branding, specialty products manufacturing and China as market which are the more aggressive and relatively new emerged strategies.

Moreover, Hong Kong electronics companies claimed they emphasis on the degree of specialization, which is the construct that contributes to the active adoption of business strategies such as cost leadership, product line breadth, environmental scanning, specialty products and China as market positively significantly.

From this result, it can be seen that the trend of running business in the industry changed. Environmental scanning, specialty products manufacturing and China as market were not as important as recent years. Due to the open door policy of China and the ever-close relationship between Hong Kong and her motherland, the potential market in China should not be neglected.

On the other hand, the result shows that companies are now starting to realize the importance of branding and taking their steps onto the road of differentiation.

Furthermore, Chinese owned companies are now changing their attitude towards marketing research. They pay more attention to the environmental scanning and treat this as an investment for reducing risks instead of expenses without return.

\subsection{Adoption of Technology Strategies}

For the technology strategies, paternalism and information networking are directly correlated with OEM and imitation, which are regarded as a traditional strategy, as assumed. Astonishingly, both of them are positively related with process innovation at the same time. This indicated a change in organization behaviour in recent years that more emphasis was put on the aspects of process innovation which is proved to bring desire overall satisfaction and effective adaptation.

About another CFB variable, low degree of specialization, it is positively related to aggressive technological posture, new product development and ODM; while inversely related to process innovation and imitation. As seen in Table 8, new product development helped companies bring positive outcome in overall satisfaction and effective adaptation. ODM even contributed in the financial performance to the companies. This result illustrates that electronics companies are paying more and more attention on the newly suggested strategies instead of the "older" ones. 


\section{Recommendations}

Chinese family businesses are long being described as "conservative" in doing business; avoid generating innovative ideas by always following the beaten path and therefore causing the slow growth of the corporation. The study provides hints to policy makers in the industry to improve their companies' performances.

\subsection{Adoption of Business Strategies}

As mentioned above, system performance is positively related to cost leadership, product line breadth, environmental scanning, branding, specialty products and China as market in the category of business strategies (Table 7). These strategies are proved to have significant relations with various characteristics of CFB.

For financial performance purpose, among the above variables, environmental scanning should be stressed. CFB qualities e.g. information networking (.30) and specialization (.38) encouraged environmental scanning have a higher trend of encouraging financial performance of company. This may due to the better understanding of the market trend and the clients' needs through marketing research. However, other CFB nature e.g. personalism of networking (-.15), antipathy to external management (-.23), formalization (-.33), centralization (-.18) and short-termism (-.32) discouraged this critical factor from occurring. Therefore, company who want to gain financial benefit in the industry is advised to adjust their company culture from those that are discouraging the financial growth to those which are supporting the company in a long-term sense.

\subsection{Adoption of Technology Strategies}

For technology strategies, system performance is positively related to aggressive technological posture, new product development, new process development and ODM while negatively correlated to OEM (Table 7).

Regarding the overall satisfaction and effective adaptation of companies, attention should be pay to new product development and process innovation. Both of them showed positive relationships with these two areas. Figures indicated that new product development is significantly correlated to specialization (.72), short-termism (.66) and centralization (.41). Here comes the reason to explain the latter two. Short-termism usually goes hand in hand with sales-oriented. As the target sales figure is clear, the sales force has definite target to try and achieve. Satisfactory overall performance is, therefore, generally observed. For centralization, as there is limited delegation of authority by the chief executive, decision making process is simpler, quicker and with more flexibility compared with complex layers of organization structure. This provides the answer why centralization is positively related to effective adaptation, the issue that companies should put an eye on. Management should define job duties clearly so that every employee know what they are exactly supposed to do in order to avoid duplication of manpower. Moreover, according to the well-known economics theory about specialization, "practice makes perfect" does exist. A clearer division of labour helped the company indeed. Hence, companies may focus more on these aspects if they want to outperform others.

\subsection{Relationship Between Nature of CFB and Strategies Used}

Although nature of a company may not have direct influence in performance, companies should note that the degree of CFB-ness affects the selection of strategies and thus, having short-term or long-term impacts towards companies. Company culture is, in fact, a prerequisite of being success in a competitive sector, and should be treated as a foundation stone before setting any strategy.

\section{Limitations and Future Research}

This study provides some valuable information on relationships between nature of Chinese Family Business (CFB) and strategies adopted and between strategies used and company performance. Yet, several questions remain unanswered.

Due to cost limitation and time constraint, questionaires are done without the presence of interviewer. While the analysis has been variance-based, the variance in question may not be large enough to represent substantive differences. Moreover, the levels of up-grading strategies are not mentioned. Different respondent may have different interpretation on the word "up-grade". Both slightly up-grade approach and severe up-graded approach away from traditional strategic choices may also be interpretated as "up-graded". The absence of interviewer leads to the disability to control, explain and clarify the variables to respondenets one by one. The research focuses on the CFB-ness of corporations in relation to strategies adopted and company performances. However, only parts of the characteristics of the Chinese Family Business defined by Harjani were chosen (according to the relevance with the hypothesis set) to be used in this study. There may involve subjective judgment. It would be more satisfactory to include the full set of fifteen variables in the research.

Finally, all studies that treat business performance as a dependent variable has interpretive limitations for 
fundamental reasons described by March and Sutton (1997). Direction of causation might possibly be reversed (Child, 2000), with performances determining the strategies adopted. For instance, firms placing greater emphasis on ODM performed better and thus, supporting the up-grading prescription. However, better performance may simply the result of random processes. On top of this, performance may affect the strategies adopted also. The case may be that only if the firms with better performance have the ability to spend more and invest in the up-grading strategies. Such problems of interpretation of causation necessarily arise in variance-based analyses and they cannot be resolved.

\section{Conclusion}

In conclusion, this study enriches the framework by previous paper. Statistics showed that newly proposed business and technology strategies i.e. environmental scanning, aggressive technological posture, new product development, new process development and ODM have higher trend of encouraging performances of companies. Findings in this study provide insights and directions to policy makers to improve their companies' performances, survive in the market and succeed in the industry.

\section{References}

Adler, N., Campbell, N., \& Laurent, A. (1989). In search of appropriate methodology: From outside the People's Republic of China looking in. Journal of International Business Studies, 20(1), 61-74. https://doi.org/10.1057/palgrave.jibs.8490351

Adler, P. S., Campbell, M., \& Laurent, L. (1989). Technology strategy: a guide to the literatures. Research in Technological Innovation, Management and Policy, 4, 25-151.

Berger, S., \& Lester, R. (1997). Made by Hong Kong. Hong Kong: Oxford University Press.

Brown, S., \& Eisenhardt, K. (1995). Product development: past research, present findings and future directions. Academy of Management Review, 20(2), 343-378.

Carney, M., \& Gedajlovic, E. (2001). Corporate governance and firm capabilities: a comparison of managerial, alliance and personal capitalism. Asia Pacific Journal of Management, 18, 335-354. https://doi.org/10.1023/A:1010649828352

Carney, M., \& Gedajlovic, E. (2002). The co-evolution of institutional environments and organizational strategies: the raise of family business groups in the ASEAN region. Organization Studies, 23, 1-29. https://doi.org/10.1177/0170840602231001

Carney, M., \& Gedajlovic, E. (2003). Strategic innovation and the administrative heritage of East Asian family business groups. Asia Pacific Journal of Management, 20, 5-26. https://doi.org/10.1023/A:1022062428231

Child, J. (2000). External examiner's comments on C. Ma's Thesis.

Claessens, S., Djankov, S., \& Lang, L. H. P. (1999). Who controls East Asian corporations? World Bank Working Paper. Washington, DC: World Bank.

Davies, H., \& Ko, D. (2006). Up-grading and performance: the role of design, technology and business strategy in Hong Kong's electronics industry. Asia Pacific Journal of Management, 23(3), 255-282. https://doi.org/10.1007/s10490-006-9001-8

Davies, H., \& Ma, C. (2003). Strategic choice and the nature of the Chinese family business. Organization Studies, 24(11), 1405-1435. https://doi.org/10.1177/0170840603249003

Dillman, D. (1978). The Total Design Method. New York: Wiley.

Harjani, H. (1999). A comparison of small Chinese and Indian trading business in Hong Kong: an empirical study based on the concept of the Chinese family businesses. Hong Kong: Department of business studies, the Hong Kong Polytechnic University

Hayes, R., \& Wheelwright, S. (1984). Restoring Our Competitive Edge: Competing Through Manufacturing. New York: Wiley.

Hong Kong SAR Government. (2005). Hong Kong Year Book 2005. Hong Kong: Hong Kong SAR Government.

Hong Kong Trade Development Council. (1998). Hong Kong's Manufacturing Industries: Current Status and Future Prospects. Hong Kong: Research Department, HKTDC, Hong Kong.

Hong Kong Trade Development Council. (2000). Competitiveness and Prospects of Hong Kong's OEM, ODM and Brand Name Business. Hong Kong: Hong Kong Trade Development Council. 
King, A., Y. C., \& Leung, D. H. K. (1975). The Chinese Touch in Small Industrial Organization. Hong Kong: social research center, Chinese university of Hong Kong.

Oster, A. (1990). Modern Competitive Analysis. New York: Oxford University Press.

Redding, S.G. (1991). Weak organizations and strong family business networks. In G. Hamilton (Ed.), Business Networks and Economic Development in East and Southeast Asia (pp. 153-168). Hong Kong: centre for Asian studies, University of Hong Kong.

Redding, S. G. (1992). Capitalist Cooking Lessons. Asian Business, 28(11), 50-52.

Redding, S. G. (1995). Overseas Chinese networks: understanding the enigma. Long Range Planning, 28(1), 61-69. https://doi.org/10.1016/0024-6301(94)00071-C

Redding, S. G., \& Pugh, D. S. (1986). The formal and the informal: Japanese and chinese organization structures. In the Enterprise and Management in East Asia (pp. 153-168). Hong Kong: centre for Asian studies, University of Hong Kong.

Reif, R., \& Sodini, C. (1997). The Hong Kong electronics industry. In S. Berger, \& R. Lester (Eds.), Made by Hong Kong (pp. 186-215). Hong Kong: Oxford University Press.

Ryan, E. (1961). The Value System of a Chinese Community in Java, Phd dissertation. Harvard University.

Schulze, W. S., Lubatkin, M. H., Dino, R. N., \& Buchholtz, A. K. (2001), Agency Relationships in Family Firms: Theory and Evidence. Organization Science, 12(2), 99-116. https://doi.org/10.1287/orsc.12.2.99.10114

Shapiro, D. M., Gedajlovic, E., \& Erdener, C. (2003). The Chinese family firm as a multinational enterprise. International Journal of Organizational Analysis, 11(2), 105-122. https://doi.org/10.1108/eb028965

Thurow, L. (1987). A weakness in process technology. Science, 1659-1663. https://doi.org/10.1126/science.238.4834.1659

Weber, M. (1951). The Religion of China: Confucianism and Taoism. The free press.

Whitely, R. (1990). Eastern Asian Enterprise Structure and the Comparative Analysis of Forms of Business Organization. Organization Studies, 11(1), 47-74. https://doi.org/10.1177/017084069001100105

Whitley, R. (1991). The Social Construction of Business Systems in East Asia. Organization Studies, 12(1), 1-28. https://doi.org/10.1177/017084069101200102

Whitley, R. (1992). Business Systems in East Asia: Markets, Firms and Societies. London: sage.

Wong, S. L. (1985). The Chinese family firm: a model. The British Journal of Sociology, 366(1), 58-72. https://doi.org/10.2307/590402

Yu, T. (1998). Adaptive Entrepreneurship and the Economic Development of Hong Kong. World Development, 26(5), 897-911. https://doi.org/10.1016/S0305-750X(98)00013-8

Zahra, S., \& Covin, J. (1993). Business Strategy, Technology Policy and Firm Performance. Strategic Management Journal, 14, 451-478. https://doi.org/10.1002/smj.4250140605

\section{Appendix i}

Table 1. The CFB according to Redding

\begin{tabular}{ll}
\hline Small scale & Personalistic networking \\
Simple organizational structure & Cost-conscious and efficient \\
Centralized decision-making & Weak in creation of market recognition \\
Reliance on dominant chief executive & Discouragement of professional management \\
Family ownership and control & Limited ability to support growth \\
Paternalistic organizational climate & High degree of strategic adaptability \\
\hline
\end{tabular}

Source: Adapted from Redding (1995: 64). 


\section{Appendix ii}

Table 2. The CFB according to Whitley

\section{The Nature of the Firm}

Small to medium size

Low capital intensity

Limited discretion assigned to managers

Risk managed by limiting commitment and maximizing flexibility

Strategic change on an opportunistic basis

Business specialization is high

Integration through personal ties and ownership

Growth focused on volume and expansion and opportunistic diversification

\section{Market Organization}

High degree of interdependence among firms

Very limited degree of vertical integration

Commitment to exchange partners is limited to family-like connections

Scope of exchange relations with partners is low outside family-like connections

High degree of reliance on personal knowledge and reputation

Horizontal coordination through long-term commitments based on personal ties

Low reciprocity of commitment

\section{Coordination and Control}

Importance of owner's personal authority is very Work group and task autonomy is low high

Reliance on family for top management is high

Managerial involvement in the work group is low

Centralization of decision-making is high

Importance of group morale is low

Delegation to middle management is limited

Omniscience of senior managers is presumed to be high

Small number of middle managers

Mangerial style is paternalistic

Low reliance on formal procedures

Source: Whitley (1992: 65, 71, 77).

\section{Copyrights}

Copyright for this article is retained by the author(s), with first publication rights granted to the journal.

This is an open-access article distributed under the terms and conditions of the Creative Commons Attribution license (http://creativecommons.org/licenses/by/4.0/). 